\title{
MANAGEMENT OF SPECIAL FOOD PRODUCT - AN OPPORTUNITY FOR MARKET EXPANSION IN THE REGION AND EUROPEAN FOOD MARKET
}

\author{
Mirjana Nedović ${ }^{1}$, Lovro Babić ${ }^{2}$
}

\begin{abstract}
This research is based on conducted surveys with potential consumers of a food product called "kulen" a Slavonian traditional dry fermented salami, as an indigenous Croatian product, covering two counties (Osiječko-Baranjska and Vukovarsko-Srijemska). The surveys include the manufacturer's attitude toward the special traditional product kulen, their place in the market, strengths, and weaknesses. The aim of this paper is to analyze the market for kulen food products, based on consumers' responses and their willingness to purchase the product. The results showed that in the two counties, most consumers purchase salami once a week from a Croatian market - a crucial indicator for consumption of quality products.

With Croatia's accession to the European Union, Croatian manufacturers have found themselves within the unified European market. This primarily means an expanding market where they can sell more of their products. However, the entry of new producers into the Croatian market would also increase competition. In such case, some manufacturers will have to lower the price of their products to become more competitive, while those whose products have unique geographical indications, designations of origin, and traditional specialty would certainly be able to set a higher price for their products.
\end{abstract}

JEL Classification Numbers: L11, Q13, DOI: http://dx.doi.org/10.12955/cbup.v2.445

Keywords: kulen, Slavonian, Croatia, European Union, management, market performance, food production

\section{Introduction}

In Slavonia, the production of salami "kulen" has long been a tradition and represents a product that has a long-term perspective existence in the market. Slavonian dry fermented salami, kulen, is a famous traditional meat product from Eastern Croatia made without any additives, such as nitrites or ascorbic acid, and has gained excellent acceptance by international consumers. It is produced according to traditional procedure from minced pork, with the addition of salt, red pepper, hot pepper and garlic. Specific olfactory and gustatory properties of this salami have the highest influence on the consumer perception of quality (Jerković, Kovačević, Šubarić, Marijanović, Mastanjević, \& Suman, 2012). The production of kulen is widespread throughout Slavonian region, although there is an adequate number of unregistered manufacturers, which have their share of the market. Currently, there are about 100 producers of kulen in Croatia, which produce around 500 tons of kulen annually (Vukadinović, 2012). Howeiver, the market for this product type is still unorganized and a sizeable portion of the sales takes place illegally. Although great efforts have been made by the Republic of Croatia, there is still an insufficient number of authentic products, which are branded as an intellectual property. After the Croatian admission to the EU, producers of protected products will be in a more favorable position than the rest of the competition, and will be able to achieve higher profits compared to the producers of unprotected products. Therefore, it is necessary to define the problem and organize the market systematically. The aim and purpose of this study is to analyze the market and identify the most important factors that influence the purchase of kulen. Furthermore, it is also important to analyze the market potential and frequency of consumption, and to indicate the importance of product management.

\section{Product management and further possibilities}

Product management is becoming a necessary prerequisite for survival in the market. By observing specific product such as kulen, besides achieving superior quality and setting a reasonable price, the product must be intensively managed on the market after manufacturing. Therefore, it is necessary to

\footnotetext{
${ }^{1}$ Mirjana Nedović, College of Applied Sciences L. Ružička in Vukovar, Croatia, mnedovic@ @evu.hr

${ }^{2}$ Lovro Babić, College of Applied Sciences L. Ružička in Vukovar, Croatia, lovrobabic@ gmail.com
} 
convince a potential buyer of the exceptional characteristics of the product that justify higher price. To optimize the results of the product placement in a market, one needs to plan a long-term strategy for market performance, and then define the tactical activities in accordance with fluctuating market demands. For the achievement of the desired financial results, the manufacturers would have to see the possibilities of cooperation with retailers through sales and product placement. Appropriate product management could include the following activities:

- clearly defining production capacity of an OPG (individual agriculture farm),

- monitoring consistency in product quality,

- protecting the product and the name of the product,

- signing a contract with specialized retailers,

- handling the product in retail as a manufacturer,

- implementing marketing activities by exploring the market with the product specificity.

Even today some product development managers are facing intense pressure to bring world-class products into market within record time. Many factors contribute to this pressure, including acceleration in the rate of technological development, improved mass communication, more intense competition due to the maturing of markets and globalization, fragmentation of the marketplace due to changing demographics, shorter product life cycles (Ali, Krapfel, Labahn, 1995).Thus product management, as well as its further development, should clearly be the approached by a professional.

It is important to point out that many kulen producers in Croatia do not have the necessary knowledge to successfully participate in a market. Usually the sale takes place on a farm where the seller does not offer the product in an active and positive aggressive way. They usually wait for a buyer to make a first move. This attitude will certainly not contribute to significant sale and breakthrough on the market, so it is necessary to change the way of thinking when dealing with business in general.

When we consider the possibilities of entering a market, it is necessary to point out the potential danger of bad product placement, especially on foreign markets. According to Keller, Aperia, \& Georgson (2008) one of the reasons why so many companies run into trouble when going overseas is that they, unknowingly or deliberately, overlook differences in consumer behavior. Therefore, it is necessary to determine the details in habits and preferences of consumers in other countries before they go on the market, to minimize business risks.

\section{Research}

In April 2013. we conducted a survey on the attitude of kulen consumers within the area of Vukovarsko-Srijemska and Osiječko-Baranjaska County. We surveyed 80 participants. The questionnaire consisted of 12 questions, divided into three segments:

1. Analysis of the basic set,

2. Consumer perceptions about products,

3. Acceptable pricing level for respondents to purchase the product.

Close-ended questions were used when creating this survey. The consumers were surveyed based on whether they agree or disagree with some of the claims using dichotomous scale (Yes or No), and to what extent they agree with the statement using the Likert scale (1-5). The data gathered were grouped, graphically displayed, and analyzed by conventional methods of descriptive statistics, using the computer program Microsoft Excel. Table 1 lists the questions used during the survey: 


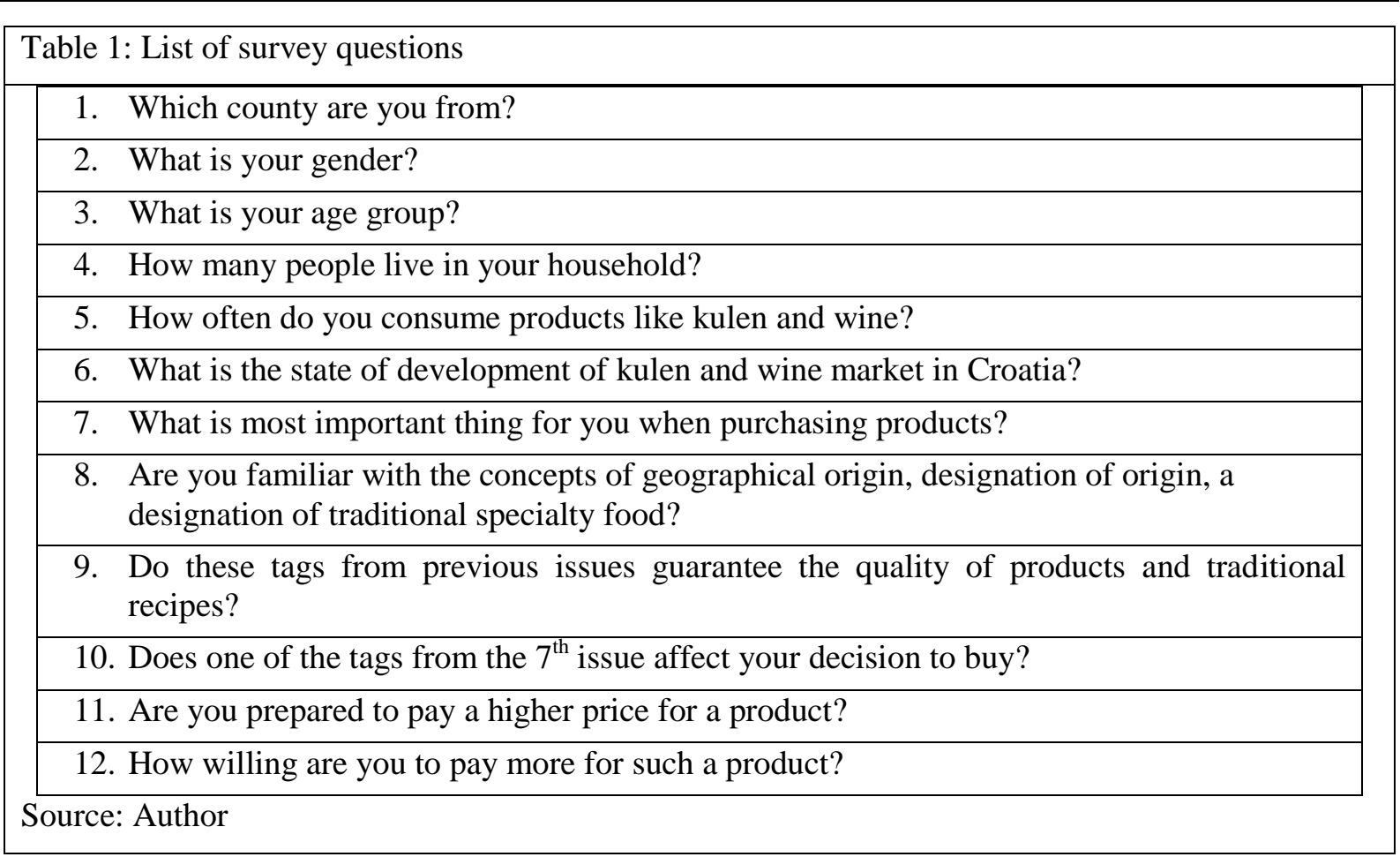

\section{Results and Discussion}

In this consumer survey, a total of 80 respondents were interviewed. $44 \%$ and $56 \%$ of them were from Vukovarsko-Srijemska County and Osiječko-Baranjska County, respectively. 62\% were female and $38 \%$ were male respondents. The largest portion of respondents, $75 \%$, belonged to the 35 -year-andyounger age group; $18.75 \%$ was from the 35 -to- 49 age group; and $25.6 \%$ belonged to the 50 -to- 64 age group.

Based on the results of the survey, in Table 1, in the category of "the number of people in a household," the majority of the respondents had a household of four persons (38.75\%), followed by respondents with a household of three persons $(25 \%)$, then by respondents with a household of more than four persons (22.5\%), and respondents from a household of two persons (11.25\%). Households with one person $(2.5 \%)$ comprised the smallest group of surveyed respondents.

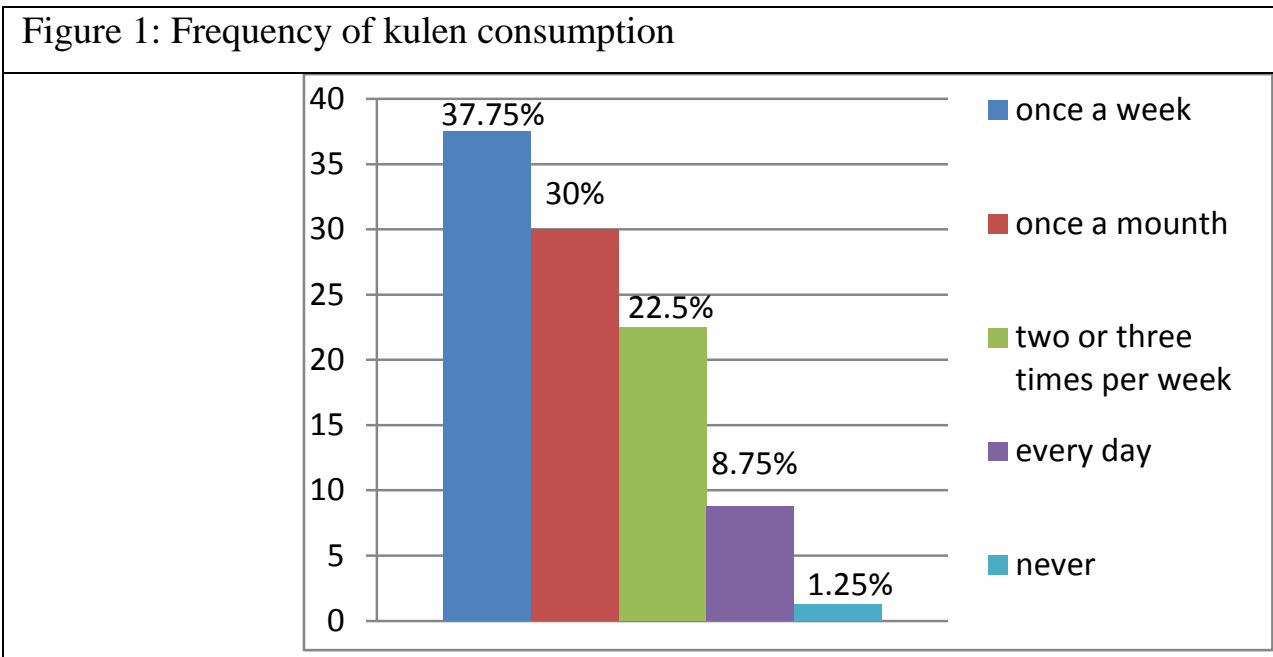

Source: Author 
In Figure 1, the frequency of kulen consumption is investigated. The largest number of respondents, $(37.5 \%)$, consumes kulen once a week; $30 \%$ consumes it once a month; $22.5 \%$ consumes it $2-3$ times a week; $8.75 \%$ consumes it every day; $1.25 \%$ of the respondents never had kulen.

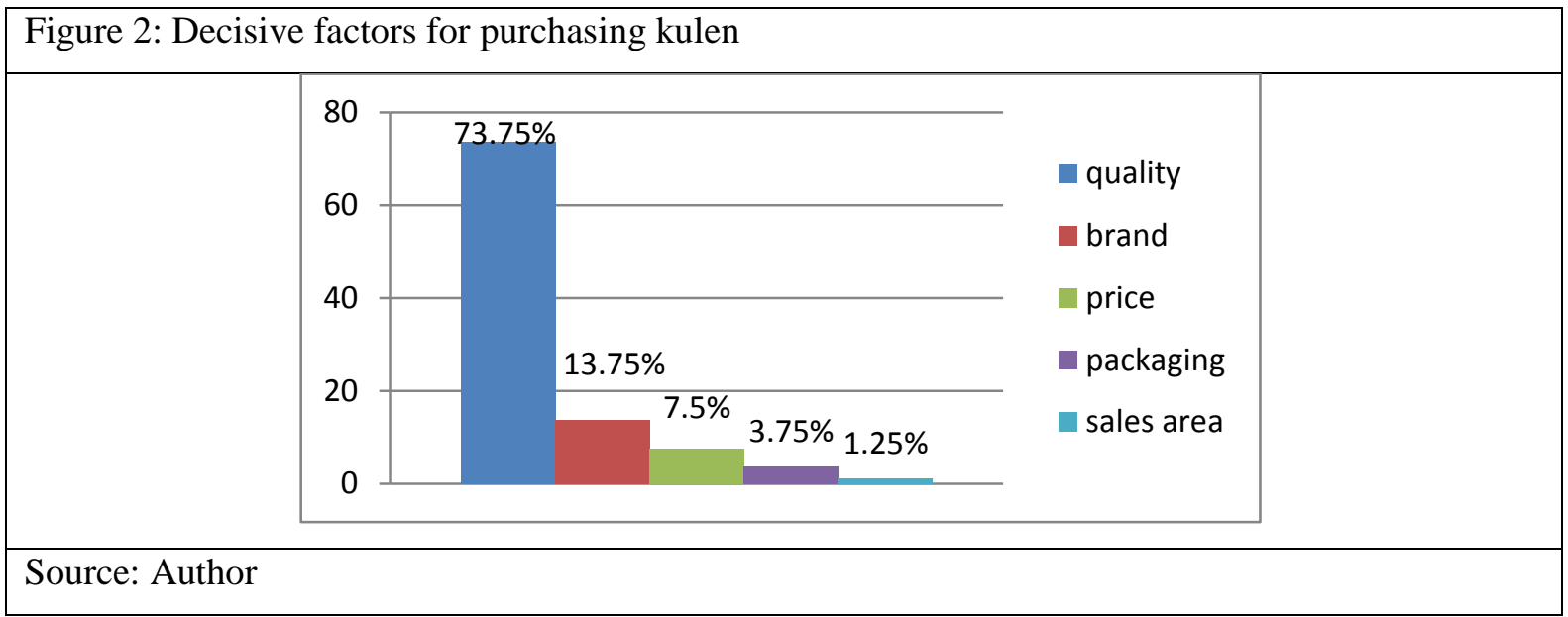

In Figure 2, we can see the most important factor for consumers when deciding to buy kulen was quality, which accounted for $73.75 \%$ of the respondents. In addition, only $13.75 \%$ of them considered the brand of kulen as the second most important factor when purchasing this product.

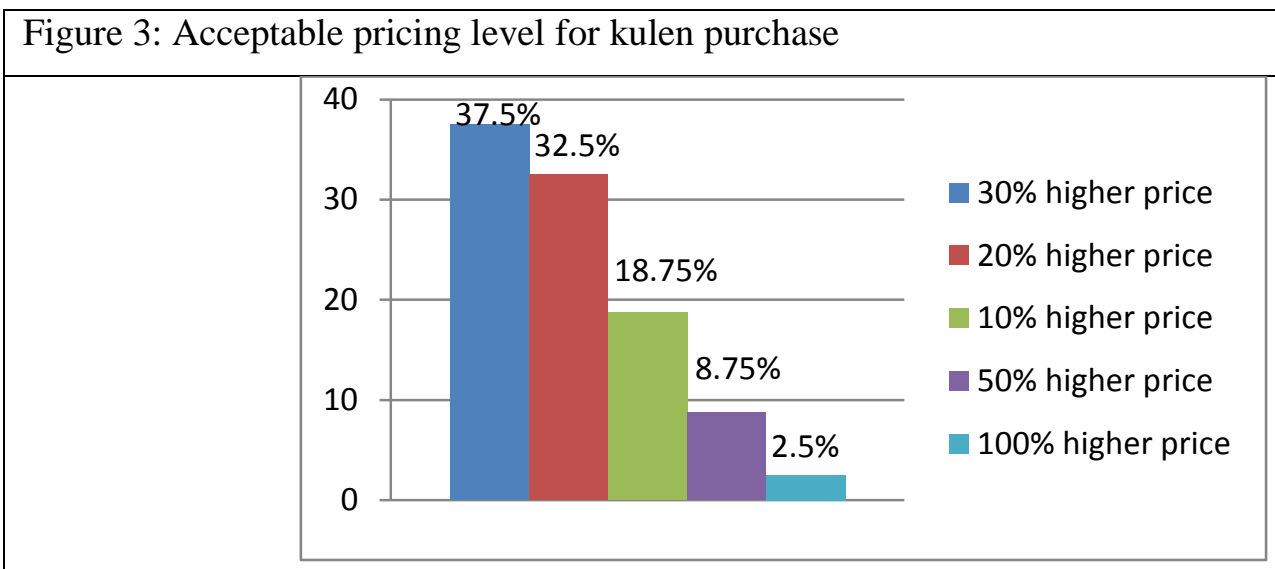

\section{Source: Author}

In Figure 3, consumer's willingness to purchase kulen, with regard to price, is investigated. For the respondents who were willing to pay a higher price for the kulen, the largest number of respondents (37.5\%) were willing to pay $30 \%$ higher price; $32.5 \%$ were willing to pay $20 \%$ higher price; $18.75 \%$ were willing to pay $10 \%$ more; $8.75 \%$ were willing to pay $50 \%$ more; and $2.5 \%$ were willing to pay $100 \%$ more. We can determine from these results that customers value product quality and authenticity over any other factor. In fact, they are willing to pay more also.

\section{Conclusion}

At the present time, when market is overwhelmed with lots of mass-produced goods, specifically with kulen included, some consumers still respond positively to authentic products made "domestically" and naturally from family farms. A product labeled as "protected" will also look more appealing to the customers and will, ultimately, be purchased at a better price.

Kulen, a Slavonian traditional salami, is protected by geographical origin. Surveyed respondents have made it clear that a large number of them (37.5\%) consume these agricultural food products once every week. The largest number of respondents $(73.75 \%)$ considers quality as the most important 
factor when making a purchase; and when it comes to price, the largest number of respondents (37.5\%) are willing to pay $30 \%$ more and so on. In order to succeed in the kulen business, both in the domestic and European Union market, small producers will certainly need to give special attention to the product management and the final consumption where marketing activities are crucial. In addition, they would have to consistently monitor modern production technology and product quality. The Final goal for these producers and manufacturers is the "survival" and progressive share in the markets.

\section{References}

Ali, A., Krapfel, R., \& Labahn, D. (1995). Product innovativeness and entry strategy: impact on cycle time and break-even time. Journal of Product Innovation Management, 54-69.

Gugić, J., Cerjak, M., Batelja, D., Lodeta, K., \& Goreta Ban, S. (2012). Segmnentacija potrošača lubenice na splitskom tržištu. [Segmnentacija consumer watermelon at the Split market]. Paper presented at Croatian and 7th International Symposium on Agriculture. Opatija: Faculty of Agriculture, University of Zagreb.

Ilak Peršurić, A., \& Červar, A. (2012). Stavovi posjetilaca o izložbi vina "Vinistra" [Attitudes of visitors about wine exhibition "Vinistra"]. Paper presented at Croatian and 7th International Symposium on Agriculture. Opatija: Faculty of Agriculture, University of Zagreb.

Jerković, I., Kovačević, D., Šubarić, D., Marijanović, Z., Mastanjević, K., \& Suman, K. (2012). Authentication Study of Volatile Flavour Compounds Composition in Slavonian Traditional Dry Fermented Salami "kulen." Food Chemistry, 813822 .

Kelle, K. L., Aperia, T., \& Georgson, M. (2008). Strategic Brand Managment. A European Percpective. Trans-Atlantic Publications, Inc.

Kovačić, D., Cerjak, M., Lang, P., \& Markovina, J. (2011). Suvremeni prehrambeni trendovi. [The modern food trends]. Paper presented at Croatian and 6th International Symposium. Abbey: Agronomy School University of Zagreb.

Vukadinović, N. (2012). Slavonski kulen gubi dah u tržišnoj utakmici. [Slavonian Kulen losing breath in the market competition]. Voice of Slavonia. 